\title{
FALCIFORM LIGAMENT ABSCESS: REPORT OF A CASE
}

Valdinaldo Aragão de Melo, Gustavo Barreto de Melo, Renata Lemos Silva, João Fernandes Britto Aragão and José Eraldo Marques Rosa

MELO VA de et al. - Falciform ligament abscess: report of a case. Rev. Hosp. Clín. Fac. Med. S. Paulo 58(1):37-38, 2003.

Falciform ligament abscess is rare. We report a case of a 65-year-old man who presented with right upper quadrant abdominal pain, postprandial fullness, and fever. Computed tomography disclosed a cylindrical mass in the anterior abdomen that aroused suspicion of a hepatic abscess. At laparoscopic surgery, an abscess of the falciform ligament was found and drained. Two months later, the patient developed recurrence of the abscess secondary to acute calculous cholecystitis. Abscess drainage and cholecystectomy were performed. The presence of right uppper quadrant abdominal pain, epigastric tenderness, fever, leukocytosis, and a mass in the anterior abdomen should arouse suspicion of falciform ligament abscess. Its treatment consists of abscess drainage.

DESCRIPTORS: Falciform ligament. Abscess. Gallbladder. Drainage. Calculous cholecystitis.

\section{INTRODUCTION}

Few cases of falciform ligament abscess have been reported. This implies that the pathology of falciform ligament abscess is poorly understood, and many surgeons may encounter one without being able to identify it. Therefore, we report a case of falciform ligament abscess secondary to acute calculous cholecystitis.

\section{CASE REPORT}

A 65-year-old man presented with right upper quadrant abdominal pain and postprandial fullness without weight loss. These symptoms had appeared 2 months earlier.

At admission, his body temperature was $38.5^{\circ} \mathrm{C}$. His heart beat was 82 systolic. Abdominal examination disclosed a palpable mass that was slightly tender. Laboratory studies were normal for gamma-GT (48 U/L), aspartate transaminase (40 U/L), and alanine transaminase (21 U/L). However, his white blood cell count was 18,000 per cubic millimeter. Other laboratory tests were normal.

At abdominal ultrasound, the gallbladder was enlarged, and a sonolucent mass that was interpreted as a hepatic abscess was found in the right upper quadrant. Computed tomography revealed a cylindrical mass in the anterior abdomen that aroused suspicion of a hepatic abscess. It extended along the course of the falciform ligament to the porta hepatis (Fig. 1).

Laparoscopic exploration confirmed the presence of an abscess in the falciform ligament, which was drained percutaneously. The postop-

From the Department of Medicine of the Federal University of Sergipe and São Lucas Hospital.

Received for publication on February 26, 2002. erative course was satisfactory. However, 2 months later, the patient presented with the same symptoms of the disease. A recurrence of the falciform ligament abscess and acute calculous cholecystitis were found. Therefore, cholecystectomy and another abscess drainage were performed. A follow-up ultrasound showed no evidence of intra-abdominal abscess.

\section{DISCUSSION}

In a parasagittal plane, the falciform ligament is oriented from the umbilicus to the diaphragm and contains the ligamentum teres and the remnant of the umbilical veins. In the area of the liver, its peritoneal layers are divided into the coronary ligaments. It also has an interhepatic course between the left and the quadrate lobe of the liver. Therefore, there is a space that potentially provides the communication be- 


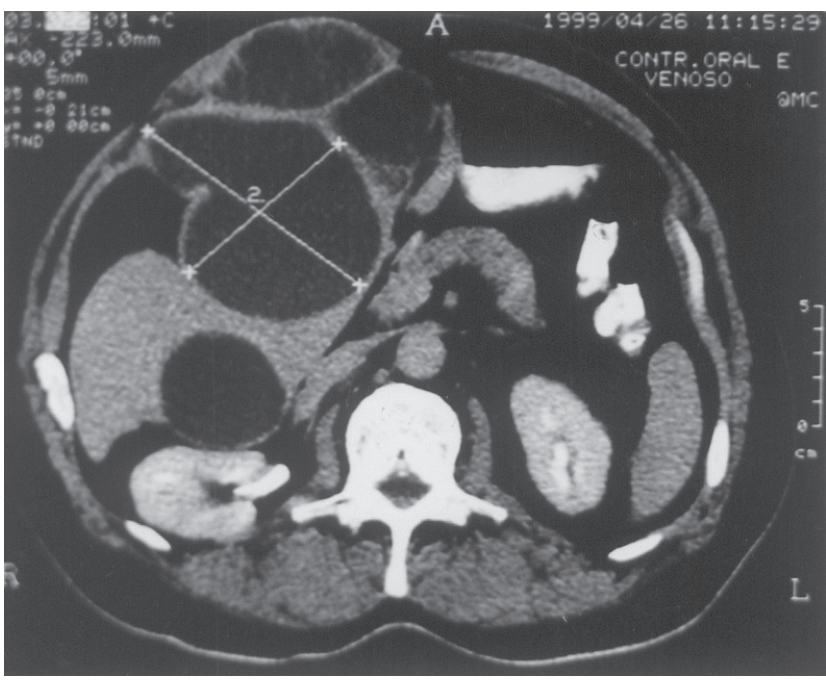

Figure 1 - Falciform ligament abscess as a cylindrical mass in the anterior abdomen at computed tomography.

tween the gallbladder and the falciform ligament.

Clinically, the presence of an abscess is very uncommon. Few articles were found regarding it in the literature ${ }^{-}$ 5 . The occurrence of falciform ligament abscess secondary to ventriculope- ritoneal shunt infection has been reported $^{3}$. Three other reported cases were caused by cholecystitis ${ }^{1,2,5}$. Cholecystitis is considered the cause of the falciform ligament abscess presented here, either by direct or lymphatic spread. Additionally, abscess of the falciform ligament due to umbilicus infection in children has been reported ${ }^{4}$.

On abdominal examination, right upper quadrant pain, distension, and epigastric tenderness is common ${ }^{1,3,5}$. Some cases may present spiking fevers and leukocytosis in laboratory studies ${ }^{3}$.

Ultrasound and computed tomography scans should be helpful in detecting the presence of an abscess and in evaluating the existence of cholecystitis, even though it may be difficult to properly visualize the gallbladder. On computed tomography scanning, free air limited to the area surrounding the falciform ligament indicates the presence of an abscess ${ }^{1}$.

It is important to differentiate between falciform ligament abscess and hepatic abscess because antimicrobials are efficient in treating the latter, while being almost useless to the former ${ }^{4}$.

Drainage by laparoscopic surgery is the treatment of choice for falciform ligament abscess.

\section{RESUMO}

MELO VA de e col. - Abscesso de ligamento falciforme: relato de caso. Rev. Hosp. Clín. Fac. Med. S. Paulo 58(1):37-38, 2003.

Abscesso de ligamento falciforme é raro. É relatado um caso de um homem de 65 anos que apresentou dor no quadrante superior direito do abdome, plenitude pós-prandial e febre. A tomografia computadorizada revelou uma massa cilíndrica no abdome anterior que causou suspeita de abscesso hepático. Na cirurgia laparoscópica, um abscesso de ligamento falciforme foi encontrado e drenado. Dois meses depois, o paciente desenvolveu recidiva do abscesso secundário a colecistite aguda calculosa. Drenagem do abscesso e colecistectomia foram realizados.
A presença de dor no quadrante superior direito, febre, leucocitose e abaulamento no abdome ântero-superior deve causar suspeita dessa patologia. Seu tratamento consiste de drenagem do abscesso.

DESCRITORES: Ligamento Falciforme. Abscesso. Vesícula biliar. Drenagem. Colecistite Calculosa.

\section{REFERENCES}

1. BROCK JS, PACHTER HL, SCHREIBER J et al. - Surgical diseases of the falciform ligament. Am J Gastroenterol 1992; 87(6):757-758.

2. DOSCHER W, CHARDAVOYNE R, TEICHER I - Abscess of falciform ligament. N Y State J Med 1980; 80(7 Pt 1):11311133.

3. LAUCKS SS, BALLANTINE TVN, BOAL DK - Abscess of the falciform ligament in a child with a ventriculoperitoneal shunt. J Pediatr Surg 1986; 21(11):979-980.
4. LIPINSKI JK, VEGA JM, CREMIN BJ - Falciform ligament abscess in the infant. J Pediatr Surg 1985; 20(5):556-558.

5. SONES PJ, THOMAS BM, MASAND PP - Falciform ligament abscess: appearance on computed tomography and sonography. Am J Roentgenol 1981; 137:161-162. 